\title{
Completing College: Focus on the
}

\section{Finish Line}

Hunter R. Boylan, Appalachian State University

Barbara J. Calderwood, Appalachian State University

Barbara S. Bonham, Appalachian State University

\author{
Reprinted White Paper, Copyright 2017 \\ National Center for Developmental Education \\ www.ncde.appstate.edu
}

\section{EXECUTIVE SUMMARY}

This paper contends that, although there is much to commend in the remediation reform movement, it is unlikely to attain its goals. These goals include the Lumina Foundation's target of having $60 \%$ of Americans attain a degree or certificate, the Bill and Melinda Gates Foundation's goal of doubling the number of low income students who earn a postsecondary degree, and President Obama's goal of the U.S. having the world's highest percentage of degree holders by 2020. This is due to several factors including (a) the failure to distinguish between remedial and developmental education, (b) the limited focus of reform on remedial and gateway courses, (c) the mistaken assumption that there is a causal relationship between remediation and attrition, (d) the failure to address students' reading problems, (e) the nonsystematic nature of most reform efforts, ( $f$ ) and the subsequent failure to address other causes of student attrition and the difficulties of many community college students' lives. There are, of course, many commendable efforts to improve student performance in the community college. This paper describes the most popular of these efforts. It also discusses data on their effectiveness. In spite of their success, community colleges will need to do more if they are to dramatically enhance degree and certificate completion, particularly among minority, low income, and first-generation students.

The authors suggest that there are three phases involved in attaining the dramatic increase in college completion desired by foundations and government. The first phase is to improve the quality of teaching and learning in community college classrooms. This will require a substantial faculty development effort, particularly for adjunct instructors.

The second phase is to fully integrate courses and student support services. At present, the academic and the student affairs divisions of community colleges usually operate randomly and independently of each other. Their full impact cannot be obtained unless support services are more directly linked to course goals and objectives and courses are more directly connected to the services designed to support them.

The third phase is expanding the connections between community colleges, public schools, and community services. High schools and colleges need to collaborate more closely to insure that the exit standards of secondary education are more consistent with the entry standards of postsecondary education. In addition, community colleges need to establish closer ties and better relationships with services available in the local community to address the varying nonacademic needs of our least advantaged students.

The authors then provide concrete examples of how community colleges might implement all three phases of student completion. Some of these examples represent new thinking about how community college courses and services might be organized and delivered. Many, however, represent things we already know but have, for a variety of reasons, failed to implement.

n 2013, the Lumina Foundation established the goal of having $60 \%$ of Americans attain a quality degree, certificate, or other postsecondary credential by 2025 (Lumina Foundation, 2013). The Bill and Melinda Gates Foundation's U.S. Higher Education Program set its goal to double the number of low-income students in the U.S. who earn a postsecondary degree (Bill and Melinda Gates Foundation, 2009). Meanwhile, the Obama Administration introduced the goal of having the U.S. become the world's most educated nation as measured by percent of postsecondary degree holders in the population by 2020 (The White House
Briefing Room, 2010). A combination of government and foundation funding has established or supported a number of organizations attempting to bring policy and research to bear in accomplishing these goals. It is unlikely however, that any of these goals will be met by current reform efforts.

This is not because these efforts lack federal or foundation funding. They do not lack for good ideas and good people to implement them. Nor do they lack for intelligence, effort, or integrity. Instead, they lack a broad enough focus to accomplish their goals. Reform efforts focus on a relatively small piece of the process 
of college student retention and completion while ignoring larger and equally or even more important pieces. With few exceptions they have focused on finding quick and simple solutions to the problems of student underpreparedness and low retention and graduation rates. Adherents then claim that these solutions can be successfully applied with cookie cutter regularity and minimal funding and supported by state and local policies.

The best example of such solutions are found in the movement to reform community college remediation. Most of those involved in this reform movement start off by misunderstanding the difference between remediation and developmental education. Developmental education is the integration of courses and support services guided by the principles of adult learning and development (Boylan, 1990; Saddlemire, 1978). Remediation generally refers to stand-alone courses addressing pre-college content. Unfortunately, a variety of researchers, policy makers, and news reporters use these terms interchangeably, thus confusing the issue from the outset.

It has become clear through a variety of studies that stand-alone remedial courses are often ineffective for many students (Bailey, Jeong, \& Cho, 2009; Boatman \& Long, 2010; Complete College America, 2012; Matorell \& McFarlin, 2007). This should come as no surprise. Students are typically placed in these courses using marginally accurate assessment instruments and questionable placement scores (Hughes \& Scott Clayton, 2011). Furthermore, students are typically uninformed about the consequences of placement test scores and unprepared to perform well on commonly used assessment instruments (Hodura, Smith Jaggars, Mechur Karp, 2012). Research suggests that, although more than $60 \%$ of community college students place into one or more remedial courses, fewer than a third of these students are likely to complete them (Bailey, Jeong, \& Cho, 2009).

Some organizations have seized upon this research and declared that remediation is the cause of students failing to complete college (Complete College America, 2012). Others have misunderstood what has been studied and reported that developmental education is a barrier to college completion. In fact, it is only remedial courses that have been addressed by the research, not developmental education.

The mantra that "Remediation doesn't work, we have to do something else" has often been used as an excuse to promote whatever reform is being championed by a particular organization. It has also led policy makers to erroneously believe that remediation causes attrition. Although it is a well-known fallacy to confuse correlation with causality, policy makers continue to act as though participation in remediation is the primary reason students fail to complete college. Indeed, poor remediation may be one of the many causes of student attrition, but it is far from the only one or even the major one. Others include such things as illness, finances, personal and family issues, quality of teaching, expectations, engagement, and employment (Hunt, 2013; Kuh, Kinzie, Schuh, \& Whitt, 2011; Ray, Aspland, \& Barret, 2014; Willkoxson, Cotter, \& Joy, 2011)

The belief that remediation causes attrition has led policy makers, researchers, and postsecondary education leaders to focus their reform efforts almost exclusively on reforming remedial courses, gateway courses, teaching models, or curricula. It is almost as if policy makers and leaders believe that, if remediation was eliminated or reformed, the barriers to college completion would be removed. Furthermore, they have confused remediation with developmental education and implemented policies to eliminate or reduce developmental education as well as remediation. As a result, some strong developmental programs that have contributed to student success and completion have been eliminated because of the perception that remediation and developmental education are synonymous. Having done so, policy makers in several states have targeted remediation for reform, mistakenly called it developmental education, and then claimed to have addressed the problem of college noncompletion. In fact, they have only focused on the problem of high noncompletion rates in remediation or high failure rates in gateway courses. This is consistent with their narrow view of what affects student success and completion. Ignoring a host of situational (health and family), demographic (income and ethnicity), and affective (values and attitudes) factors only exacerbates the problem.

This is not to say that the reforms fail to contribute to student success. Jobs for the Future, for instance, has done a good job of summarizing the research on some of the more popular reforms in remediation and found that many of them produce positive results for participating students (Juncos \& Collins, 2015). The Community College Research Center and other individuals and organizations have studied contemporary reform efforts and confirmed that there 
are benefits to most of them (Cho, Kopko, Jenkins, \& Jaggars, 2012; Kalamkarian, Raufman, \& Edgecombe, 2015).

Unfortunately, most of these reforms are targeted specifically toward eliminating, reforming, or redesigning community college remediation. And, as previously noted, although remediation does need to be reformed, it is developmental education that should be implemented. The plethora of other factors contributing to student attrition are generally left unaddressed, particularly when reformers see remedial courses as the sole or major cause of the problem. As a result, no matter how many reforms and innovations are introduced to remediation, high levels of student attrition will continue to occur in the nation's community colleges. This will insure that the completion goals of many private and government organizations will not be met.

\section{The Limitations of Current Reform and Innovation Efforts}

If one looks carefully at the available data on the reform of remediation, several things become clear. Most of the innovative methods proposed to improve student completion work to one degree or another. If properly implemented, just about any of the popular innovations in community college instruction will "move the needle." This is clear. Unfortunately, it is also clear that they are not always properly implemented and, even when they are, they frequently fail to move the needle far enough.

Many foundations and nonprofit organizations are advocating the bringing of promising innovations to scale. Historically, many promising innovations have had only a limited effect, mainly because they have been confined to particular programs or departments rather than being implemented throughout their host institution, because many people in postsecondary institutions are resistant to change, and because scaling efforts are expensive and time consuming (Soricone \& Pleasants McDonnell, 2016). However, considerable thought and research has gone into bringing innovations to scale in recent years (Asera, Pleasants McDonnell, \& Soricone, 2013; Public Agenda and Achieving the Dream, 2011; Soricone \& Pleasants McDonnel, 2016). This thought and research will probably contribute to improving the extent to which promising innovations are available to all students and this is positive. Unfortunately, it still may not be sufficient to bring about the dramatic changes envisioned by the Gates Foundation, the Lumina Foundation, and the federal government.

Improving mathematics pass rates from $12.3 \%$ to $62.3 \%$ (Complete College America, 2016) or improving English composition pass rates from 39\% to $75 \%$ (Cho, Kopko, Jenkins, \& Jaggars, 2012) or increasing the percentage of students who pass college-level mathematics courses to $30 \%$ or higher (Zachry Rutschow \& Diamond, 2015) represent commendable efforts. But these improvements or any others brought about by contemporary innovation will not be sufficient to meet the goals of the Lumina Foundation, the Gates Foundation, or the Obama Administration. Even if $62.3 \%$ of community college students successfully complete their first college-level mathematics class (Complete College America, 2016), they will still have to enroll in, pay for, and earn a minimum of a $C$ in at least nineteen other courses to attain an associate degree. Even if $75 \%$ of community college students successfully complete college composition (Cho, Kopko, Jenkins, \& Jaggars, 2012), they will still have to manage their adult responsibilities, respond to life crises, and maintain their motivation for however long it takes them to complete the rest of their curriculum. This is the missing link in the reform movement. Much of the legislation that results from the movement appears to be based on the flawed assumption that reforms will enable all students to be equally able to move forward; be successful in subsequent college courses; and complete a degree, certification, or diploma after participating in a particular innovation or reform. On the positive side, the Lumina Foundation (2016) and the Community College Research Center (Bailey, Smith Jaggers, \& Jenkins, 2015) have advocated for a more comprehensive approach to reform but, thus far, their work has had minimal impact on legislators.

As research points out, successfully completing the first college-level course will definitely improve the odds of a student completing college (Adelman, 2006; Boylan, Bliss, \& Bonham, 1997). But it will not improve the odds dramatically. No matter how well students do in courses targeted for reform, they will still have to run the gauntlet of challenges to their graduation. And this is where the problems lie. The overwhelming majority of contemporary reform efforts, as effective as some may be, suffer from several shortcomings.

First, they tend to focus primarily on remedial courses and gateway courses. Almost all of the most popular contemporary reform efforts measure the outcomes of their activities in terms of passing or bypassing remediation and passing initial college-level courses in English and mathematics. They do not focus on student success in post-gateway courses.

Second, reform efforts tend to focus on structural changes in courses and curriculum. They change the models used to teach remedial and gateway courses and they change the content of the courses. But they do not change the systems that these courses are part of or the rewards, expectations, or values of those systems (Bailey, Smith Jaggars, \& Jenkins, 2015).

Third, reform efforts tend to be disconnected from the rest of the institution. They often operate as 
"pet projects" of the college president or as specialized activities within a program or department. Even when they are scaled up, the scaling often involves simply serving larger numbers of students rather than creating a stronger connection between the reform and the institution (Soricone \& Pleasants McDowell, 2016).

Fourth, reform efforts tend to be random rather than systematic. They involve parts of the academic segment of the postsecondary system, but they do not engage the entire system. The reforms themselves may be systematic, but they are usually not well integrated into the larger institutional system. Course numbers, methods, and content may be changed but the Registration, Financial Aid, Academic Advising, Career Counseling, and Student Activities Offices often continue to go about "business as usual" ( Bailey, Smith Jaggars, \& Jenkins, 2015).

Fifth, reform efforts either accidentally or deliberately de-emphasize reading as a basic skill necessary for college success. Reform efforts in Florida and North Carolina, for instance, are aimed at reducing the number of students who enroll in remediation (The Florida Senate, 2013: North Carolina State Board of Community Colleges, 2014). Although this is a laudable goal, one of the methods of doing this is to integrate reading and composition courses. The result is to reduce or eliminate the number of completely reading focused courses available to students. The integration of reading and writing is a good idea and one that will benefit the majority of students (Hearn \& Snell, 2013). Unfortunately, for the weakest readers, there is no course work available to them focused specifically on developing reading skills. Yet most experts would agree that reading is a foundational skill for college success (Gray, 2014; Holschuh \& Paulson, 2013; Pugh, Pawan, \& Antommarchi, 2000). According to ACT, only 44\% of 2016 high school graduates who participated in ACT assessment were considered college ready in reading (ACT, 2016).

Finally, and perhaps most damaging, reform efforts often do not take into account those specific student characteristics contributing most to attrition. Researchers generally agree that that the following background factors have a substantial impact on attrition in college (Atwell \& Lavin, 2007; Brock, 2010; Editorial Projects in Education Research Center, 2011; Falcon, 2015):

1. Coming from a low income family,

2. Being an ethnic minority,

3. Being a first-generation student

4. Performing poorly in prior education.
Other factors also contribute to the failure of many students. In a study of over 213,000 students enrolled at public universities in the Midwest, Soria and Bultmann (2014) found that working-class students are more likely to feel alienation, isolation, and lack of belonging than middle- and upper-class students. It is likely that working class students attending community colleges experience the same feelings with subsequent impact on their performance. Based on a review of the literature, Kasworm, (2012) describes four circumstances that contribute to the attrition of adults over 25-years-old: (a) time required for college work, (b) cost of college attendance, (c) institutional policies, and d) discrimination against older students on the part of some faculty. She further points out that adult responsibilities often prevent full-time college attendance. However, there is considerable contemporary emphasis on completing college as a full-time student (Complete College America, 2011). This recent emphasis contributes to working adults' feelings of inadequacy because they simply cannot attend full-time given the other commitments in their life to work and family (Kassworm, 2012).

Only a few current reform efforts address these characteristics. Among the most effective is the Accelerated Study in Associates Programs (ASAP) of the City University of New York. This program not only provides financial incentives such as free tuition, books, and metro transportation, it also requires full-time enrollment and offers small class size, learning communities, and built-in academic, career, special programs, and personal counseling. These latter services help students address the effects of being a first-generation and/or a minority student and the financial assistance helps them overcome the effects of coming from low income backgrounds. Furthermore, the program serves its students throughout their academic careers, not just their first year (Kantor, 2011). Between 2007 when the program was introduced and 2010, participants' graduation rates were $54.9 \%$ as compared to $21.1 \%$ for a control group (City University of New York, 2011).

Another successful program that provides long-term support is the State of Washington's Integrated Basic Education and Skills (I-Best) program. This program focuses on lower skilled and English as a Second Language (ESL) students in career programs. Adult education, ESL, and career faculty at community colleges jointly design occupational courses leading to a certificate. These courses integrate basic skills and the vocabulary and expectations of a career field with 
the content of occupational courses. The program supports participating students as they progress through an occupational program by providing mentoring, tutoring, and advising for a year or more until students earn a career certificate or a degree (Zachry Rutschow \& Scheider, 2011). As in the ASAP program, students attend classes and are supported over time with mentoring and services that help them deal with the consequences of poverty and discrimination.

Perhaps the most systematic and comprehensive completion reform plan is proposed by Bailey, Smith Jaggars, and Jenkins (2015) from the Community College Research Center. These authors criticize what they refer to as the contemporary "cafeteria style self-service model" which forces students to choose courses and programs of study from a bewildering array of options and to do so with very little guidance" (p. 3). Instead, they advocate restructuring the community college curriculum to provide "guided pathways" (p. 3) that are clearly structured programs of study leading to particular certificates or degrees coupled with improved instruction integrated with support services and intensive orientation and advising. Ironically, this sounds a lot like the definition of developmental education. The guided pathways model also utilizes some of the remedial education reforms to accelerate student progress through remedial courses.

Bailey and his colleagues at the Community College Research Center are to be commended for developing a model and a set of recommendations offering a genuinely systematic and comprehensive approach to improving college completion. Unlike other reformers, Bailey, Smith Jaggars, and Jenkins (2015) address the variety of institutional and systemic failures that contribute to student attrition. Although the guided pathways model has much to recommend it, it focuses on reforming the structure of the American community college. It does not directly address the spectrum of issues that contribute heavily to the attrition of low income and minority students, although it may do so indirectly (Jenkins, Smith Jaggars, \& Bailey, 2016). Because the guided pathways model is new, few institutions have had a chance to fully implement it. As a result, there is, as yet, little research on its efficacy. However, the components of the model are well grounded in research (Jenkins, Smith Jaggars, \& Bailey, 2016).

The guided pathways model would appear to work best with full-time students: those who can commit to a course sequence and those who have the wherewithal, either through financial aid or their own resources, to regularly pay for tuition, fees, books, and supplies. But as Michael Rose points out:

I am continually struck by the hardships experienced by so many community college students. To be sure, middle class students from stable and secure backgrounds attend community college but, depending on the location of the college, many students come from low-income to destitute families; have to work 30 or more hours a week; live in cramped housing, some of which is sub-standard; are food insecure; and have health problems that are inadequately treated. For some, there are worries about immigration. Some must contend with prior involvement in the criminal justice system while others struggle with addiction. (Rose, 2016, p 2)

According to the American Association of Community Colleges, more than half of the ethnic minority students participating in postsecondary education are enrolled in community colleges. Furthermore, 58\% of community college students receive some form of financial aid, $22 \%$ of full-time community college students work full time and $40 \%$ work half time, $62 \%$ are enrolled part-time, and $36 \%$ of these students are the first in their family to attend college (American Association of Community Colleges, 2016). Given these statistics, in spite of its potential benefits, the guided pathways model will not serve all community college students, nor do its authors claim that it does (Jenkins, Smith Jaggars, \& Bailey, 2016).

Nevertheless, the ASAP Program, the I-Best Program, and the guided pathways model feature what others do not. They reorganize the curriculum and the way it is delivered for all courses, not just remedial and gateway courses. They provide support services throughout students' college careers. Their efforts are also systematic and effect entire groups of students in an organized, coherent, and purposeful manner. Unfortunately, efforts such as these are far too few. The vast majority of reforms are focused on short-term solutions that only address completing remediation and passing gateway courses.

\section{A Summary of Short-Term Reform Efforts}

To be fair, many short term reform or innovation efforts have improved student outcomes to one degree or another. Unfortunately, they do not improve outcomes sufficiently to meet the goals of foundations and government. Furthermore, they are not of sufficient duration to impact upon students as they progress past remedial and gateway courses.

\section{Accelerated and Integrated Reading and English}

Among the more successful of these innovations is that of accelerated and integrated reading and English composition originally implemented at Chabot College in California by Katie Hearn (2013). Both Jobs for the Future and the Community College Research Center support this model which involves a 1 semester, 4-hour English composition course. This course accelerates student progress by combining 2 semesters' work into a single semester (although a 2-semester option is also available to 
students). Students who complete the course are eligible to enroll in college-level English. The course not only integrates reading development with composition but also emphasizes critical thinking and familiarizing students with college-level rewards and expectations.

Based on a recent report from Jaggars, Hodura, Cho, and Xu (2016), students participating in the integrated reading and English composition course were $24 \%$ more likely to complete a college-level English course than nonparticipants. They also completed an average of 4.2 more credit hours over three years. However, both the accelerated and non-accelerated students passed the college-level English course at similar rates (Jaggars, Hodura, Cho, \& Xu, 2016).

Another popular innovation, this one championed by Complete College America, is the corequisite model of remediation. This model was originally called the Accelerated Learning Program (ALP) and developed at the Community College of Baltimore County by Peter Adams and his colleagues (Adams \& McKusick, 2014). Instead of requiring remedial courses as a prerequisite to enrollment in college-level courses, corequisite remediation provides remediation simultaneously with college-level content in a single semester.

According to Complete College America (2016), West Virginia community colleges were able to improve their pass rates in gateway mathematics courses from $14 \%$ to $62 \%$ using the corequisite model. Using the same model, they found Tennessee community colleges improved their pass rates in these courses from $12.3 \%$ to $63.3 \%$. Cho, et al. (2012) studied students enrolled in the Accelerated Learning Program at the Community College of Baltimore County between the fall of 2007 and the fall of 2011. They found that $75 \%$ of the students who participated in the ALP passed college-level English whereas only $39 \%$ of those who did not participate in the ALP passed the course.

\section{Modular Mathematics}

Modular mathematics is another model widely used in community colleges to improve student performance in developmental mathematics. This model has its origins in the personalized instruction movement of the 1970s and involves breaking the content of developmental mathematics into a series of discrete units or modules (Eyre, 2007). Students may then demonstrate mastery by taking tests covering the material in the modules. An entire course may consist of 12-16 modules and students may complete the course as fast as they are able to complete the required number of module tests, thus allowing them the opportunity for accelerated completion of developmental courses. This model was initially implemented in Virginia community college mathematics courses and later in mathematics courses in North Carolina community colleges.

The Community College Research Center and the Virginia Community College System have both issued reports on this model. Kalamkarian, Raufman, and Edgecombe (2015) found that the percentage of remedial students who completed college-level math increased from $8 \%$ to $18 \%$ in 2012. The Virginia Community College System (2014) reported that developmental mathematics success rates increased from 35\% to $40 \%$.

An innovative approach developed by Virginia Tech and promoted by the National Center for Academic Transformation is the "Emporium Model" (Twigg, 2011). This model combines computer technology that allows students to spend their time actually working mathematics problems with human assistance to answer questions when difficulties are encountered. It also utilizes a modular approach to the organization and mastery of course material. Emporium classes are usually held in large computer laboratories where instructors and/or instructional assistants circulate to help students resolve problems.

In a study conducted at Jackson State Community College, the Emporium approach contributed to raising posttest scores by $15 \%$ and increasing mathematics course pass rates by $44 \%$ (Twigg, 2011). Twigg also reported a study by the Tennessee Board of Regents indicating that students were twice as likely to earn a $\mathrm{C}$ or better in remedial math when taught using the model as students who took a traditional remedial course.

The Carnegie Foundation for the Advancement of Teaching has developed two pathways to improving student performance in remedial and college-level mathematics (Yamada \& Byrk, 2016). One pathway, Statway, integrates remedial and college-level content into a year-long course. The content includes statistical concepts and problem solving, and the methodology involves collaborative learning. The other pathway, Quantway, is a single-semester quantitative reasoning course that prepares students to succeed in a second single-semester college-level course in quantitative reasoning.

An analysis of data from 18 community colleges participating in the Statway project indicated that only $6 \%$ of students took traditional remedial mathematics and passed a college-level mathematics course in 1 year. Over a period of 4 years, an average of $48 \%$ of those participating in Statway completed both remedial and college-level courses in 1 year. Results for the Quantway project were similar. Among participating institutions, only $21 \%$ of students enrolled in traditional remedial mathematics courses passed the 
course within 1 year. An average of $56 \%$ of students participating in Quantway passed the remedial course within 1 semester (Huang, Hoang, Suleyman, \& Thorn, 2016). A further study of Statway reported that these gains were consistent regardless of gender, ethnicity, or mathematics placement scores (Yamada \& Bryk, 2016).

Uri Treisman of the Dana Center at the University of Texas-Austin, who worked with Carnegie in the development of the Statway and Quantway models, also developed the New Mathways Project. This project, implemented in cooperation with the Texas Association of Community Colleges, has developed a variety of nonalgebra based mathematics courses taught in an accelerated format. The format enables students to complete developmental mathematics and college-level mathematics within a year. These courses are also developed in line with the numeric skills required in social science, health, and liberal arts professions (Charles A. Dana Center, 2016).

Baseline data from 2011-2014 cohorts of Texas community college students indicated that only $26 \%$ of those placing into developmental mathematics courses passed them with a C or better. Of these only $20 \%$ went on to enroll in and pass a college-level mathematics courses within 3 years. In contrast, $65 \%$ of those participating in New Math Pathways developmental courses passed within 1 year and 30\% of those participating in the New Math Pathways program passed a college-level mathematics course within only 2 semesters (Zachry Rutschow \& Diamond, 2015).

All of the reform efforts described here show a positive impact on retention and completion. However, none of them represent a "magic bullet" or a panacea. All of them appear to focus on only a single phase of student success: remedial and gateway courses. Even after the reforms have been implemented and brought to scale, students will still have to negotiate the college curriculum, make wise academic and life choices, pass at least 60 hours of credit with a $\mathrm{C}$ or better, overcome language barriers, and respond to the effects of racism and poverty to attain an associate degree or transfer to a university.

\section{The Three Phases of College Success}

There are at least three phases to college retention and completion. Upon entering higher education, students must be prepared for college-level courses and successfully complete gateway courses. Retention through these initial courses is important but continued retention through graduation is equally or even more important.

\section{Phase One}

The first phase is helping students pass the courses in which they are enrolled. This is, no doubt, why so many reformers focus on remedial and gateway course completion as the object of their efforts. The first and probably easiest phase in improving college completion is getting students to successfully complete their first college courses, whether they are remedial or college level. Many reforms have focused on restructuring courses, but they ignore one of the most important components of student success: quality instruction. Quality instruction requires that instructors understand and apply adult and developmental theory and the lessons of research on teaching and learning. Developmental theory, in relation to faculty professional development, also relates to the faculty mindset of seeing students as containing a trait of college readiness versus seeing students as whole people who are in the process of developing the skills of college readiness. When faculty utter statements such as "that student is definitely not college material," they are indicating the former mindset. Developmental theory would suggest that students are not one way or another but have the capacity to develop appropriate skills given the right supports, curriculum, and pedagogical strategies. Other insidious assumptions about a person's being may lie in the trait mindset as well, such as hidden biases about ethnicity, gender, and other traits a student cannot control and which should not be used to determine readiness for college.

It is no longer sufficient for instructors to simply teach the way they have been taught. They must be able to design and deliver instruction that is effective for the adult learners who attend $21^{\text {st }}$ century community colleges, and they must do this using the most current research available. It is disappointing that few of the reforms imposed upon remediation have addressed issues such as culturally responsive teaching, inclusive instruction, adult learning theory, brainbased instruction, or cognitive psychology. Research and theory from these areas have great potential for improving the quality of instruction for all students. By and large, however, this body of knowledge has been ignored by reformers. 


\section{Phase Two}

The second phase in student retention and completion is getting the entire college to engage in systematic behaviors that contribute to student success. This involves the integration of academic and student affairs. It requires greater collaboration between student affairs professionals and academic and career faculty. Both groups should increase the time and resources devoted to enhancing students' knowledge of how to behave and succeed in college as well as supporting the development of subject matter knowledge.

As those who study college student retention consistently point out, keeping students in college is the responsibility of everyone at the institution, not just a particular course or program (Noel, Levitz, \& Saluri, 1985). There is a role to play in student completion for everyone at the college, from the grounds crew, to the cafeteria workers, to the president. But they must know what their roles are and how to play them. This, of course, requires rethinking the roles of various college personnel as well as retraining them to fulfill appropriate new roles.

\section{Phase Three}

The third phase in student retention and completion is expanding the college system to engage with secondary education as well as community educational and support systems that can be deployed to assist students to complete college. The role of high schools in preparing students for success in college is often underplayed or overlooked. High schools have the capacity for not only preparing students for college courses but also helping them understand and respond to college rewards and expectations. Unfortunately, such preparation is usually reserved only for those whose high school teachers and counselors consider them to be "college material." Basic skills and GED programs should also introduce students to nonacademic skills important to postsecondary success.

Meanwhile, the communities in which colleges are located provide a variety of services beneficial to college completion. Many community colleges lack the resources to provide a full range of services to students. However, quite a few of the services that might contribute to the success of college students, such day care or legal aid, are available in the community. Working more productively with high schools and community services is an important step in promoting college completion.

\section{Integrated Services for College Completion}

These phases of action leading to increased college completion are illustrated in Figure 1. They involve teaching and learning in the curriculum, integrating the institutional system, and collaborating with secondary education and the community. Each one of these phases makes some contribution to enhanced college completion. But it requires all three working in a systematic manner to enhance college completion to the degree that is necessary to accomplish corporate and government goals for postsecondary education (see Figure 1).

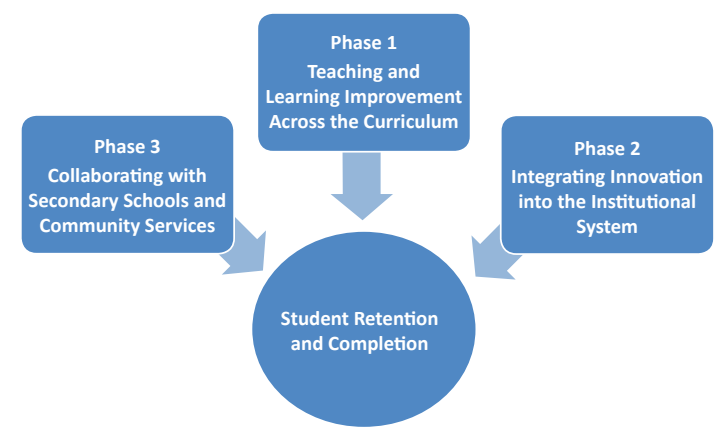

Figure 1. The three phases of action to increase college completion.

\section{Teaching and Learning Improvement}

In his classic study of community college instruction, Norton Grubb (1999) pointed out that, for institutions claiming to emphasize quality teaching, community colleges provide surprisingly little support for it. Many community colleges provide little oversight of instructors, few rewards for good teaching, and limited professional development opportunities to improve teaching. In his follow up book on basic skills instruction (Grubb, 2012), Grubb finds the situation even worse in remedial courses. It stands to reason that the weakest students would profit most from the best quality instruction. Yet the substantial majority of those teaching remedial courses are adjunct faculty (National Center for Education Statistics, 2008)., For the most part, these faculty receive little orientation to their work, little training to do it, and little support to do it right (Grubb, 2012).

This is not to say that full-time faculty are necessarily better teachers than part-time faculty. But full-time instructors at least have resources at their disposal to improve their instruction. Faculty development centers, online training programs, attendance at conferences, and participation in workshops are often provided to full-time faculty but rarely available to part-time faculty.

One of the best investments that community college leaders can make, therefore, is in professional development for adjunct faculty (Eney \& Davidson, 2006). This professional development might be made available through any number of methodologies. Examples might include common readings, interactive internet programs, on campus workshops, video conferencing, faculty inquiry groups, and mentoring by senior faculty. 
Currently, much of the professional development that takes place in the community college is more or less random. The topics of professional development activities are not always consistent nor do they necessarily reflect what instructors need to know to support student retention and completion. A primary topic for professional development should include adult development and learning theories with particular attention to lessons from research regarding cognitive neuroscience (Taylor \& Marienau, 2016). Community colleges are dealing with adult students, and yet few instructors avail themselves of the literature on adult development and learning. This is also true about research on adult teaching and learning and cognitive processing. There is a great variety of research and literature focusing on how students learn, including important work in the area of cognitive neuroscience. All community college faculty should be familiar with these bodies of literature, and these topics should form the basis of the faculty development efforts.

Training on innovative approaches to teaching and learning should also be part of this effort. Contemporary professional development activities are often focused on learning how to implement whatever innovations have been adopted by the college. A college might adopt a particular innovation and plan to bring it to scale, but the innovation will neither work well nor be brought to scale unless those participating in it are well-trained, understand the innovation, know various ways of implementing it, and have some say in how it is implemented. To the extent possible, the training should involve faculty in understanding theory supporting the models and in planning the finer points of innovation implementation. As Bailey, Smith Jaggars, and Jenkins (2015) point out, top down implementation of innovation without the meaningful involvement of instructors is generally ineffective.

Many colleges are phasing out stand-alone reading courses in favor of integrated reading and writing. This will probably help underprepared students who already read at the high school level or above. Students whose reading level is at middle school and below, however, will need substantially more reading instruction than is typically provided in an integrated reading and writing course. In fact, they will need reading instruction integrated throughout all of their courses. Training community college faculty in techniques for teaching reading is, therefore, a necessity.

Finally, faculty development efforts should focus on engaging students. There is a well-documented relationship between student engagement with faculty and student success (Center for Community College Student Engagement, 2016; Kuh, Kinzie, Schuh, \& Whitt, 2010; Quaye \& Harper, 2015). The more faculty engage in meaningful ways with students, the more successful students are likely to be in their courses and in college. Stipulating and reinforcing clear learning goals, using active learning techniques, getting students to think about their learning, being inclusive, and establishing a sense of community and safety in the classroom are examples of engagement techniques that contribute to student learning. They are also examples of topics that should be included in faculty development programs.

These topics should be the foundation for faculty development activities related to teaching today's college students, particularly those from minority, low income, or first-generation backgrounds. Institutions cannot continue to expose the weakest students to the poorest instruction and expect to improve college completion rates. Students who are most at risk are also most in need of the highest quality of teaching. Ultimately, the success of students in any course depends upon what happens in individual classrooms between individual instructors and their students. To make sure the right things happen in those classes community colleges need to:

- plan professional development activities based on assessing the needs of faculty,

- develop clearly articulated and systematic programs to meet these needs,

- provide ongoing, not episodic, faculty development activities,

- utilize a variety of methods for delivering faculty development,

- require that faculty describe what they have changed as a result of professional development

- incentivize participation in faculty development.

\section{Integrating the Institutional System}

There has been a long-standing bifurcation in postsecondary education of student affairs and academic affairs. Typically, community colleges have two different deans or vice presidents responsible for these areas. Typically, they have little to do with each other.

The student affairs staff offers their programs to whatever random group of students appears at their doorstep. The academic affairs division offers its courses to whatever random group of students enrolls. There is no effort made to see that the neediest students get the best instruction or the most support. This must change in order to attain the objectives of the college completion agenda. Student affairs professionals and academic faculty must increase their collaboration and the integration of their courses and services. Faculty must do more to inform their students about the rules and expectations of college, and student affairs professionals must do more to promote and reinforce the academic behaviors necessary for success in class. Academic advisors must 
also spend more time learning from faculty, and faculty must engage more with academic advisers. All those who interact with students should be responsible for conveying important knowledge and skills to students and encouraging the appropriate behaviors and expectations of college culture.

ACT (2015) reports that lack of college knowledge such as the information and behavioral skills necessary to for successful matriculation in academe is a major requirement for college readiness. These skills include interpersonal communication, problem solving, help seeking, task management, study strategies, and personal decision making. They also include informational knowledge such as how to obtain financial aid, register for classes, calculate a grade point average, get career development assistance, find tutors, or seek advice and counseling. As early as 1980, Boylan (p.11), called these "academic management" skills and argued that underprepared students generally did not begin college with them. He also suggested that such students were in danger of attrition unless they developed these skills early in their college careers.

Student affairs professionals deal with the enhancement of these skills and knowledge on a regular basis, yet many students are totally unaware of the assistance these professionals can provide. It is well known among student support professionals that the students most in need of their services are least likely to voluntarily participate in them (Collins \& Simms, 2006; Winograd \& Rust, 2014). Meanwhile, instructors tend to focus on content and process skills in their subject areas and view their roles entirely in terms of their discipline. They, too, should be promoting participation in support services and working to integrate what they do with the work of advisors, counselors, financial aid officers, and career development specialists. Integrating the efforts of both sets of professionals is essential to improving college completion.

Such integration requires that instructors and student affairs professionals work together to find ways of communicating college knowledge to students. They must also work together to promote students' personal and behavioral development. Resulting integration efforts might involve student affairs professionals visiting classes, or it might involve training faculty to communicate essential college knowledge and promote student development. It might involve student affairs professionals in teaching college knowledge and appropriate behaviors during class meetings. It might involve greater faculty participation in on-going orientation or the revision of syllabi to include problems and activities that help students develop college knowledge and appropriate academic behaviors. Faculty can help explain the rewards and expectations of academe during orientation or talk about them during class. Writing faculty can encour- age students to do research on careers of interest or to discuss their reasons for being in college. Mathematics faculty can link math problems to careers or use them to promote practical problem solving skills.

In addition to integrating academic and student affairs, colleges must also integrate the concept of completion into the culture and behavior of the college and its faculty and staff. First, it is important for college leaders to explain and support the notion that everyone from the cafeteria worker to the president is responsible for student completion. It is also necessary to provide the training required for faculty and staff to promote student completion. Furthermore, college leaders will need to find ways to incentivize the faculty and staff behaviors that will lead to supporting the completion agenda. Everyone on campus can contribute to student completion by:

- providing a consistently welcoming environment for students;

- creating a safe environment for students by refusing to tolerate bigotry, discrimination, shaming, or bullying in any college facility or activity;

- promoting a sense of community among students, faculty, and staff;

- making tutoring, counseling, advising, financial aid, and student activities readily and aggressively available to students;

- encouraging faculty and staff involvement in student and campus activities

- celebrating student success whether it be attaining a GED or graduating with a BA or AA degree.

Some institutions of higher education focus on improving "on-ramps and off-ramps" for students to more easily get back on their educational track after interruptions caused by life events outside their control. The Nevada Governor's Office of Economic Development mapped out an example of such programming (Heise, 2016), and MDRC describes general core elements shared by programs with this design. (Kruglaya \& Kazis, 2016). Also, Minority-Serving Institutions have a long tradition of serving diverse students and offer tactics Predominantly White Institutions might follow to improve supports for underrepresented student success.

\section{Collaboration with the Community and Secondary Education}

In 1986, Ernest Boyer, then President of the Carnegie Foundation, claimed that "One of our most disturbing findings is the discontinuity that exists between public schools and institutions of higher learning" (p. 254). Unfortunately, this observation is still true in many respects. The Center for Community College Student Engagement (2016) points out that most students leave high school believing they are fully prepared for college and are surprised to be placed in 
remedial courses. Many of these students completed their high school courses with $A$ and $B$ grades but are still considered undereprepared for college. The gap between expectations and reality for high school graduates is largely the result of the secondary and postsecondary segments of education failing to communicate adequately with each other (Boyer, 1986).

The academic requirements and expectations of college are different than those of high school. Generally, high school teachers are considered responsible for student learning. In college, students are responsible for their own learning. Yet few students understand this upon entry, particularly first-generation college students. Furthermore, there is often a mismatch between the subject matter as taught in high school and as taught in college (Glancy, Dounay Zinth, Anderson, Millard, \& Fulton, 2014). The difference in academic requirements between high school and college need to be identified explicitly and conveyed to students consistently. For instance, giving tests over the common core and college requirements during the junior year of high school is a good idea. But it must also be accompanied by counseling on the meaning of placement test scores, their importance for entering college students, and the ways in which they are used by colleges.

Many other students are underprepared for college because they lack knowledge of postsecondary behavioral expectations or of the processes involved in matriculation through college. The National Association of Student Financial Aid Administrators (2016) reports that low income students typically overestimate the costs of college and underestimate their capacity for meeting these costs. Bailey, Smith Jaggars, and Jenkins (2015) argue that a large number of incoming community college students are underprepared to choose a program of study or a career.

Students' lack of knowledge in these areas leads to increasing the contact load of college-level student affairs professionals who must work with students in academic advising and career counseling. It also leads to annoyance among faculty when students appear to be ignorant of the role of college or their purpose for being there. Furthermore, it leads to frustration among students who fail to understand that their own actions or inactions are causing many of the problems they face in matriculation. The contact load and the frustrations and annoyance could be eased if there was greater communication between high school personnel and academic and student affairs professionals at local colleges and expanded efforts to teach high school students about college rules, expectations, and procedures.

But it is difficult for high school teachers and staff to help prepare students for the academic and nonacademic demands of college if no one from the postsecondary sector talks with them about these demands. High school and college advising and support service professionals need to communicate on a regular and systematic basis. They need to discuss the affective and behavioral expectations of students and the rewards and expectations of colleges. In the process, they need to discover ways of communicating this information more systematically to students. Guidance counselors and college academic advisers not only need to work with each other, they also need to work with high school teachers to help communicate important information about college expectations, processes, and rewards.

Today's college students face a variety of life problems and issues. A recent report by Wood, Harris, and Delgado, (2016) found that, among California community college students, one third express housing insecurity and $12 \%$ experience food insecurity. The American Association of Community Colleges (2016) also reports that $44 \%$ of community college students work part time and $22 \%$ work full time. This often results in conflicts between the requirements of work and the requirements of college attendance.

Collaboration between agencies in the service of college completion should not be limited to public schools and colleges. In any given community there are resources for helping community members find support, services, health care, and legal advice. There are homeless shelters, prenatal care counselors for expectant mothers, community mental health agencies, legal aid societies, public health benefits for the poor, and shelters for abused spouses. Yet community college personnel rarely work with these agencies and, if they do refer students, may do so randomly.

Students with legal problems may be referred to the local Legal Aid Society by a faculty member but only if that faculty member knows of the agency or has worked with it. There are community agencies that can assist students in dealing with housing insecurity but are unlikely to do so unless someone at the college makes a referral. Community colleges need to work collaboratively with community agencies to be sure that students in need have support in dealing with life and work contingencies. In doing so, colleges should:

- take inventory of the available services in their community;

- designate individuals to establish regular contact and communication with these agencies;

- establish regular contact with community agencies that might provide support to students;

- provide something to community agencies, such as facility usage or consultation, in return for their services;

- provide general and contact information on these services to all faculty and staff who work with students

- provide training to faculty and staff on how to make referrals to these services. 


\section{Conclusion}

These ideas and others like them have been part of the conversation about postsecondary improvement for years. Some institutions have instituted many of them. Nevertheless, the systematic, institutional actions required to dramatically move the needle forward on college completion are the exception rather than the rule. One of the major reasons for this is that quality reform, innovation, and institutional change all take time, training, and money. Implementing the three phases of college completion--teaching and learning improvement across the curriculum, integrating innovation into the institutional system, and collaborating with secondary schools and community services--will not come easily. To implement them faculty, staff, and administrators will have to put in time: time to meet, time to plan, time to collaborate, and time to truly implement innovation and conduct formative evaluation of it. Unfortunately, time is a very scarce resource in American community colleges. Adapting to new technology, meeting state and federal compliance regulations, having fewer personnel resources and teaching larger classes because of cutbacks in postsecondary funding, and a host of other factors have all contributed to usurping the time available for college faculty and staff. Yet the changes required to truly expand college completion are going to take up large amounts of that very valuable time, and someone will have to pay for it.

There is a statement often seen in auto repair shops that says "I can do it fast, I can do it cheap, and I can do it well. Please select two of the above." This reality adequately states the conundrum faced by community colleges. They can implement change quickly, they can do it cheaply, or they can implement it with quality but they can only do two at once, Meanwhile, they are being called upon by legislators and state system offices to do all three at once (see Figure 2). Instead, what happens at many institutions is that community colleges do manage to implement change quickly and cheaply. Unfortunately, they are unable to provide the faculty and staff training, the support services personnel, or the financial incentives either to provide the high quality of innovation or to sustain that quality. This is the reality in states that mandate change without providing adequate time or resources. It is well past time to confront legislators and state system officers with this reality. If policy makers truly desire quality implementation of reform, they will have to provide either the time or the money necessary to attain it. In most states, community college budgets have already been stretched to the limit with subsequent challenges to quality (Boggs, 2004; Jenkins \& Belfield, 2014). Budget tightening also has the effect of reducing the amount of time available for faculty to initiate, engage, and support innovation, as fewer faculty and staff have to do more work. It is unlikely that the kind of changes that need to take place to truly move the bar on college completion can take place in such a fiscal environment. If legislators and policy makers want change and improvement, they will have to pay for it.

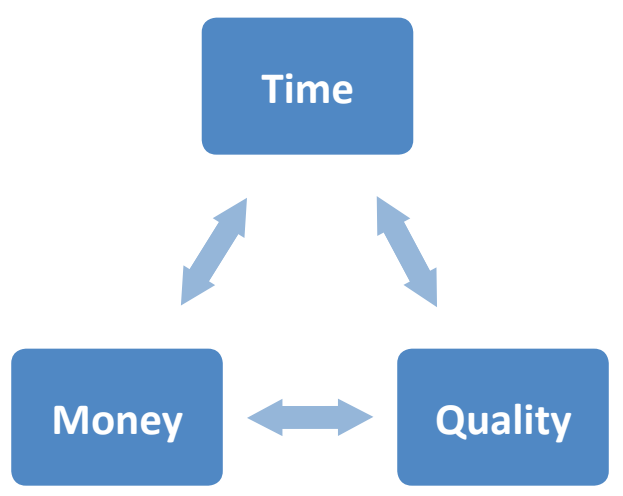

Figure 2 . The time, money, and quality conundrum.

The bottom line is that none of the ideas proposed here will take place quickly or easily. Some of those in the reform movement have promised quick results for a small investment of time and money. Others have stated that their reforms will be costly, at least at the outset, and will take a considerable amount of time to implement. The claims of the latter are likely to be more accurate. Even those claims, however, are probably optimistic unless efforts are refocused in the reform and completion agenda. This refocus should address the major student characteristics that contribute to student attrition such as being an ethnic minority, coming from a lower socioeconomic background, being a first-generation college student, or having a history of academic failure. It should address faculty training and development with particular attention to teaching reading. It should address all three phases in the college completion process, not just remediation or gateway courses. In doing so, it should also address the fact that college students are developing adults with a wide range of strengths and weaknesses; positive and negative life circumstances, advantages and disadvantages; attitudes and values; backgrounds and cultures; and hopes, fears, and frustrations. To be successful in meaningfully expanding college completion, all the players in postsecondary education, from clerks to faculty to administrators to politicians, must do a much better job of responding to all of these, not just student performance in remedial and gateway courses. Furthermore, legislators and higher education leaders must do a better job of providing time and money for quality change. Improving college completion rates, particularly for low income, minority, and first-generation students is a long distance race. It will require everyone in the race to focus on the finish line, not just first hundred meters. 


\section{References}

ACT. (2016). The condition of college and career readiness 2016. lowa City, IA: Author.

ACT. (2015). The condition of college and career readiness 2015. lowa City, IA: Author.

Adams, P., \& McKusick, D. (2014). Steps and missteps: Redesigning, piloting, and scaling a developmental writing program. New Directions for Community Colleges, 2014 (167), 15-25.

Adelman, C. (2006). The tool box revisited: Paths to degree completion from high school through college. Washington, DC: U.S. Department of Education.

American Association of Community Colleges. (2016). AACC 2016 fact sheet. Retrieved from http://www.aacc.nche.edu/AboutCC/ Documents/AACCFactSheetsR2.pdf

Asera, R., Pleasants McDonnell, R., \& Soricone, L. (2013, July). Thinking big: A framework for states on scaling up community college innovation. Boston, MA: Jobs for the Future.

Attewell, P., \& Lavin, D. (2007). Passing the torch: Does higher education for the disadvantaged pay off across the generations. New York, NY: Russell Sage Foundation.

Bailey, T., Jeong, D. W., \& \& Cho, S. W. (2009). Referral, enrollment, and completion in developmental education sequences in community colleges. New York, NY: Community College Research Center.

Bailey, T., Smith Jaggars, S., \& Jenkins, D. (2015). Redesigning America's community colleges: A clearer path to student success. Cambridge, MA: Harvard University Press.

Bill and Melinda Gates Foundation. (2009). New initiative to double the number of low-income students in the U.S. who earn a postsecondary degree. Retrieved from http://www. gatesfoundation.org/Media-Center/PressReleases/2008/12/New-Initiative-to-Doublethe-Number-of-Lowlncome-Students-in-theUS-Who-Earn-a-Postsecondary-Degree

Boatman, A., \& Long, B. (2010). Does remediation work forallstudents: How the effects ofpostsecondary remedial and developmental courses vary by level of academic preparation. New York, NY: National Center for Postsecondary Research.

Boggs, G. (2004). Community colleges in the perfect storm. Change, 36(6), 6-11.

Boylan, H. (1980). Academic intervention in developmental education. Journal of Developmental \& Remedial Education, 3(3), 10-12.

Boylan, H. (1990, July). Developmental education 101. Paper presented at the Kellogg Institute for the training and certification of developmental educators, Boone, NC.
Boylan, H., Bliss, L., \& Bonham, B. (1997). Program components and their relationship to student performance, Journal of Developmental Education, 20(3), 2-8.

Boyer, E. (1986). Smoothing the transition from school to college. Phi Delta Kappan, 68(4), 283-287.

Brock, T. (2010). Young adults and higher education: Barriers and breakthroughs to success. The Future of Children, 20(1), 109-132.

Center for Community College Student Engagement. (2016, July). Expectations meet reality: The underprepared student at community colleges. Austin, TX: Author.

Cho, S., Kopko, E., Jenkins, D., \& Jaggars, S. S. (2012). New evidence of success for community college remedial English students: Tracking the outcomes of students in the accelerated learning program (ALP) (CCRC Working Paper Number 53). New York, NY: Community College Research Center, Teachers College, Columbia University.

City University of New York. (2011). Proposals to improve success rates for students in developmental education at CUNY. New York, NY: CUNY Office of Academic Affairs. Retrieved from http://www2.cuny.edu/wp-content/ uploads/sites/4/media-assets/Report-of-theRemediation-Working-Group.pdf

Collins, W., \& Sims, B. C. (2006). Help seeking in higher education academic support services. In S.A. Karabenick \& R.S. Newman (Eds.), Help seeking in academic settings: Goals, groups, and contacts (pp. 202-223). Mahwah, NJ: Lawrence Erlbaum.

Complete College America. (2011, September). Time is the enemy. Indianapolis, IN: Author.

Complete College America. (2012). Remediation: Higher education's bridge to nowhere. Indianapolis, IN: Author.

Complete College America. (April, 2016). Co-requisite remediation: Spanning the completion divide. Retrieved from http://completecollege.org/ spanningthedivide/

The Charles A. Dana Center. (2016). New mathways project curricular materials. Retrieved from http://www.utdanacenter.org/highereducation/new-mathways-project/newmathways-project-curricular-materials/

Editorial Projects in Education Research Center. (2011, July 7). Issues A-z: Achievement gap. Education Week. Retrieved from http://www.edweek. org/ew/issues/achievement-gap/

Eney, P., \& Davidson, E. (2006). Improving supervision of part-time instructors. Journal of Developmental Education, 30(1), 2-11. 
Eyre, H. E. (2007). Keller's personalized system of instruction: Was it a fleeting fancy or is there a revival on the horizon. Behavior Analyst Today, 8(3), 317-324.

Falcon, L. (2015, June). Breaking down barriers: First generation college students and college success. Innovation Showcase. Retrieved from www.league.org/innovation-showcase/ breaking-down-barriers-first-generationcollege-student-and.college-success

Glancy, E., Dounay Zinth, J., Anderson, L., Millard, M., \& Fulton, M. (2014, October). Blueprint for college readiness: A 50-state policy analysis. Denver, CO: Education Commission of the States.

Grubb, W. N. (1999). Honored but invisible: An inside look at community college teaching. New York, NY: Routledge.

Gray, W. S. (2014). Reading difficulties in college: The natureand extent of reading deficiencies among college students. In S. Armstrong, N. Stahl, \& H. Boylan (Eds.), Teaching developmental reading (106-113). Boston, MA: Bedford/St. Martins.

Grubb, W. N. (2012). Basic skills instruction in community colleges: Inside and outside classrooms. New York, NY: Routledge.

Hearn, K., with Snell, N. (2013). Toward a vision of accelerated curriculum and pedagogy: High challenge, high support classrooms for underprepared students. Oakland, CA: Learning Works.

Heise, K. (2016, October 21). LEAP framework. Retrieved from http://system.nevada.edu/ tasks/sites/Nshe/assets/File/BoardOfRegents/ Agendas/2016/oct-mtgs/bor-joint-refs/BOR3a.pdf

Hodura, M., Smith Jaggars, S., \& Mechur Karp, M. (2012, November). Improving developmental education placement and assessment: Lessons from Community colleges across the country. (CCRC Working Paper Number 51). New York, NY: Community College Research Center, Teachers College, Columbia University.

Holschuh, J. P., \& Paulson, E. J. (2013). The terrain of developmental reading. Oak Creek, WI: College Reading and Learning Association.

Huang, M., Hoang, H., Suleyman, Y., \& Thorn, C. (2016). Community college pathways: Impact report 2014-2015. Stanford, CA: Carnegie Foundation for the Advancement of Teaching.

Hughes, K., \& Scott Clayton, J. (2011). Assessing developmental assessment in community colleges (CCRC Working Paper No. 19). New York, NY: Community College Research Center, Teachers College, Columbia University.
Hunt, P. F. (2012, September/October). Why some students leave college during their senior year. Journal of College Student Development, 53, 737-742.

Jaggars, S. S., Hodara, M., Cho, S.W., \& Xu, D. (2016). Three accelerated developmental education programs: Features, student outcomes, and implications. Community College Review, 43(1), 3-26.

Jenkins, D., \& Belfield, C. (2014). Can community colleges continue to do more with less? Change, 46(3), 6-13.

Jenkins, D., Smith Jaggars, S., \& Bailey, T. (2016, July 18). Lessons learned about guided pathways, Inside Higher Education. Retrieved from https:// www.insidehighered.com/views/2016/07/18/ what-were-learning-about-challengesimplementing-guided-pathway-reforms-essay

Juncos, A., \& Collins, L. M. (2015). Literature review: Models for developmental education redesign. Boston, MA: Jobs for the Future.

Kalamkarian, H. S., Raufman, J., \& Edgecombe, N. (2015). Statewide developmental education reform: Early implementation in Virginia and North Carolina. New York, NY: Community College Research Center, Teachers College, Columbia University.

Kantor, M. J. (2011). American higher education: First in the world. Change, 43(3), 7-19.

Kassworm, C. E. (2012). U.S. adult education: One context of lifelong learning. International Journal of Continuing and Lifelong Learning, 5(1), 1-9.

Kuh, G., Kinzie, J., Schuh, J., \& Whitt, E. (2010). Student success in college: Creating conditions that matter. San Franciso, CA: Jossey-Bass.

Kruglaya, I., \& Kazis, R. (2016, March 9). MDRC research on Career Pathways [Text]. Retrieved from http://www.mdrc.org/publication/mdrcresearch-career-pathways

Lumina Foundation. (2013, February). Lumina Foundation strategic plan: 2013 to 2016. Indianapolis, IN: Author. Retrieved from http://www.luminafoundation.org/files/ resources/2013lumina-strategic-plan.pdf

Lumina Foundation. (2016, October). Lumina Foundation strategic plan for 2017 to 2020. Indianapolis, IN: Author. Retrieved from https:// www.luminafoundation.org/files/resources/ lumina-strategic-plan-2017-to-2020.pdf

Matorell, P., \& McFarlin, I. (2007). Help our hindrance: The effect of college remediation on academic and labor market outcomes. Santa Monica, CA: RAND Corporation. 
National Association of Student Financial Aid Administrators. (2016, July). Mapping critical student decisions through college: Reviewing the literature and landscape through a behavioral lens. Washington, DC: U.S. Department of Education.

Noel, L., Levitz, R., \& Saluri, D. (1985). Increasing student retention. San Francisco, CA: JosseyBass.

North Carolina State Board of Community Colleges. (2014, March 21). Multiple measures of placement. Retrieved from http://www. nccommunitycolleges.edu/sites/default/files/ state-board/program/prog_04_multiple_ measures_2-12-15.pdf

Public Agenda and Achieving the Dream. (2011). Scaling community college innovations. New York, NY: Public Agenda.

Pugh, S. L., Pawan, F., \& Antommarchi, C. (2000). Academic literacy and the new college learner. In R. Flippo \& D. Caverly (Eds.) Handbook of college reading and study strategy research. (25-42). Mawhwah, NJ: Lawrence Erlbaum Associates.

Quaye, S., \& Harper, S. (2015). Student engagement in higher education: Theoretical perspectives and practical approaches for diverse populations. New York, NY: Routledge.

Ray, J., Aspland, J., \& Barret, D. (2014). Choosing to stay: Looking at retention from a different perspective, Studies in Higher Education, 39(9), 1700-1714.

Rogers, C. R. (1961). On becoming a person: $A$ therapist's view of psychotherapy. New York, NY: Houghton-Mifflin.

Rose, M. (2016, June). Reassessing a redesign of community colleges, Inside Higher Education.

Retrieved from https://www.insidehighered. com/views/2016/06/23/essay-challengesfacing-guided-pathways-model-restructuringtwo-year-colleges

Saddlemire, G. (1978, March). Reflections on the developmental education movement. Paper presented at the American College Personnel Association Convention, Detroit, MI.

Soria, K., \& Bultmann, M. (2014). Supporting working class students in higher education. NACADA Journal, 34(2), 51-62.

Soricone, L., \& Pleasants McDonnell, R. (2016). Scaling innovation in community colleges: A guide to action. Boston, MA: Jobs for the Future.

Taylor, K., \& Marienau, C. (2016). Facilitating learning with the adult brain in mind. San Francisco, CA: Jossey-Bass.

The Florida Senate. (2013, July 1) CS/CS/SB 1720 education. Retrievedfromhttp://www.flsenate. gov/Committees/BillSummaries/2013/ $\mathrm{html} / 501$
Twigg, C. (2011). The Emporium Model: Higher education's silver bullet. Change, 43(3), 25-34.

The White House Briefing Room. (March, 2010). Higher education. Retrieved from https:// www.whitehouse.gov/issues/education/ higher-education

Virginia Community College System. (2014). Initial review of the impact of developmental education redesign at Virginia's community colleges. Richmond, VA: Virginia Community College System.

Willcoxon, L., Cotter, J., \& Joy, S. (2011). The impact on attrition of student experiences throughout undergraduate degree studies in six diverse universities, Studies in Higher Education, 36(3), 331-352.

Winograd, G., Rust, J. P. (2014). Stigma, awareness of support services, and academic help-seeking among historically underrepresented first year college students. The Learning Assistance Review, 19(2), 17-41.

Wood, J. L., Harris, III F. \& Delgado, N. R. (2016). Struggling to survive - Striding to succeed: Food and housing insecurities in the community college. San Diego, CA: Community College Equity Assessment Lab.

Yamada, H., \& Byrk, A. S. (2016). Assessing the first two years' effectiveness of Statway: A multilevel model with propensity score matching. Community College Review, 44(3), 179-204.

Zachry Rutschow, E., \& Schneider, E. (2011). Unlocking the gate: What we know about improving developmental education. New York, NY: MDRC.

Zachry Rutschow, E., \& Diamond, J. (2015). Laying the foundations: Early findings from the new mathways project. New York, NY: MDRC. 